\title{
THE PREVENTIVE DIMENSION OF THE PROTECTION OF THE RIGHT TO LIFE UNDER THE EUROPEAN CONVENTION ON HUMAN RIGHTS
}

\author{
A DIMENSÃO PREVENTIVA DA PROTEÇÃO DO DIREITO À VIDA NO ÂMBITO DA CONVENÇÃO \\ EUROPEIA DOS DIREITOS DO HOMEM
}

Elzbieta Hanna Morawska ${ }^{1}$

\begin{abstract}
The aim of this article is pointing out to the process of redefining the nature, subject and structure of the obligations of States Parties to the European Convention on Human Rights in the field of the right to life (Article 2 of the Convention). The main author of the above redefinition is the European Court of Human Rights, hence it takes place during the interpretation and application of Art. 2 the Convention. As a result, in addition to primary negative obligations, the positive obligations are imposed on States. Strasbourg case law identifies a variety of positive measures that States are obliged to undertake in order to fulfill these positive obligations, including appropriate preventive measures. They are to prevent the materialisation of risks to the right to life, both in the case of threats from private individuals, as well as during the use of lethal force by State officials. The Court has not settled the precise catalog of these measures and the conditions for taking them. They are formulated case by case and are constantly being expanded. It can therefore be said that they are still in statu nascendi.
\end{abstract}

Keywords: European Convention on Human Rights. European Court of Human Rights. Strasbourg case law. Right to life, positive obligation to protect life, operational preventive measures.
Resumo: O objetivo deste artigo é apontar para o processo de redefinição da natureza, sujeito e estrutura das obrigações dos Estados Partes da Convenção Europeia de Direitos Humanos no campo do direito à vida (artigo 2 da Convenção). O principal autor da redefinição acima é o Tribunal Europeu de Direitos Humanos, portanto, ocorre durante a interpretação e aplicação do art. 2 a Convenção. Como resultado, além das obrigações negativas primárias, as obrigações positivas são impostas aos Estados. A jurisprudência de Estrasburgo identifica uma variedade de medidas positivas que os Estados são obrigados a adotar para cumprir essas obrigações positivas, incluindo medidas preventivas apropriadas. Eles devem impedir a materialização dos riscos ao direito à vida, tanto no caso de ameaças de indivíduos particulares quanto no uso da força letal por funcionários do Estado. O Tribunal não estabeleceu o catálogo preciso dessas medidas e as condições para adotá-las. Eles são formulados caso a caso e estão sendo constantemente expandidos. Portanto, pode-se dizer que eles ainda estão in status nascendi. Palavras-chave: Convenção Europeia de Direitos Humanos. Corte Europeia de Direitos Humanos. Jurisprudência de Estrasburgo. Direito à vida, obrigação positiva de proteger a vida, medidas operacionais preventivas.

Recebido em 18 de fevereiro de 2019 Avaliado em 27 de março de 2019 (AVALIADOR A) Aceito em 21 de outubro de 2019

\footnotetext{
$1 \mathrm{PhD}$ habilitatus of Law; Professor of the Cardinal Stefan Wyszyński University, Institute of Legal Sciences, Department of Human Rights Protection and International Humanitarian Law; 01-938 Warszawa, U1. Wóycickiego 1/3, Poland; https:// orcid.org/0000-0001-7299-0320; e.morawska@uksw.edu.pl
} 


\section{Introduction}

In the common assessment, the European Convention on Human Rights (Convention, $\mathrm{ECHR})^{2}$ is the treaty basis of one of the most effective human rights protection systems in the world. (Keller \& Sweet, 2008, p. 3). Travaux Préparatoires show that the idea of a European treaty of human rights and fundamental freedoms, combined with the mechanism of "ensuring respect for obligations arising for State Parties to the Conventions", at the helm with the European Commission on Human Rights (Commission, EComHR) ${ }^{3}$ and the European Court of Human Rights (Court, ECtHR), ${ }^{4}$ sprang from the profound conviction of common democratic values in post-war Europe being threatened. (Morawska, 2016, pp. 15-19). This was prompted, first of all, by the dramatic events of World War II, marked by unimaginable contempt for human life and dignity on an alarming scale. (Reiss, 2009, p. 293). Therefore, the Convention was to function as a sort of alarm system that was supposed to prevent and warn the state about progressing down Robertson (1963) "a road which leads far, sometimes even to Buchenwald or Dachau" (p. 6). On the other hand, that sense of looming threat was compounded by the increasingly stronger position of the Soviet Union and the "spreading of communism" in Europe. (Gordon \& Leach, 2012, p. 26. Therefore, the preparatory works were accompanied, as put by Bates (2010) and Moravcsik (2000), by "fear of the return of fascism or, in fact, fear of the coming communism" (p. 219, \& p. 6). For these reasons, the Convention was designed as a legally binding instrument of collective enforcement of human rights and fundamental freedoms. ("P. H. Teitgen's", 1975, pp. 292-294). In light of these remarks, it is understandable that Art. 2 of the Convention, constituting the right to life, is considered one of the most fundamental provisions of the Convention. Together with Art. 3, constituting the prohibition of torture, ${ }^{5}$ it is to express one of the basic values of a democratic society, for the protection of which the Council of Europe was appointed. ${ }^{6}$

However, Strasbourg case law shows that the original conditions of the Convention works have gradually lost their relevance. Consequently, the historical interpretation has been

\footnotetext{
2 Convention for the Protection of Human Rights and Fundamental Freedoms/Convention de sauvegarde des Droits de l'Homme et des Libertés Fondamentales (CETS No. 005); The Convention was opened for signature in Rome on 4 November 1950, and after obtaining the required ten ratifications, it entered into force on 3 December 1953.

3 Following the changes introduced by Protocol No. 11 to the Convention, the Court has become the only and full-time judicial body of the Convention. It was opened for signature on 11 May 1994 and entered into force on 1 November 1998 (ETS No. 155).

4 This mechanism is closely connected with the mechanism of supervision over the implementation by States Parties to the Convention of the Court's judgments. According to Art. 46 of the Convention, this supervision is exercised by the Committee of Ministers of the Council of Europe.

5 As of 1998, Art. 3 of the Convention is entitled "prohibition of torture". (Cf. Art. 2 para. 2 of Protocol 1 to the ECHR - the titles of individual chapters and articles - in the Annex to this protocol). Nevertheless, in the case law in relation to Art. 3 , the term "ill-treatment" is used, which is related to the distinction between three forms of prohibited treatment or punishment under Art. 3: torture, inhuman treatment or punishment, and degrading treatment or punishment. Thus, the gradation of prohibited forms of treatment and punishment was adopted: from the most cruel and disgraceful to the milder form, causing not so much pain and suffering but a sense of fear and humiliation.

6 The Statute of the Council of Europe was signed at a conference in London on 5 May 1949 (ETS No. 1); it has entered into force on 3 August 1949.
} 
pushed into the background and the dynamic (evolutionary) interpretation gained a domination position. ${ }^{7}$ The directives of the last interpretation require that the Convention be regarded as a living instrument and therefore its provisions are to be interpreted in the light of present day conditions. ${ }^{8}$ This is intended to help the Court in order to adequately respond to the changes of national and international legislation. As a result, the fact that relevant issue was not envisaged by the drafters of the Convention cannot prevent the Court from falling it within the scope of the Convention, hence including it in the material scope of human rights and fundamental freedoms. ${ }^{9}$

One of the effects of the dynamic interpretation of the Convention is the Court's determination of the preventive dimension of the obligations of States Parties in the field of protection of the right to life. This dimension is the result of a long process of the interpretation of the Convention by the Court. The main purpose of this article is to properly show this process and assess its effects. The starting point of this analysis is the thesis that the preventive dimension of the obligation to protect life is related to the Court's development of the positive obligations of states under the Art. 2 of the Convention. Next, the types of obligations that the Tribunal has defined in this dimension of the protection of the right to life, together with the characteristics of their subject will be presented, namely the prevention of materialization of life threat. Finally, the criteria for the Court's assessment of the fulfillment of these different obligations by States Parties will be analyzed. This will be done with particular focus on the principle of due diligence.

\section{The development of the positive obligations of State Parties under the Convention}

Historically, the right to life, as well as other human rights and fundamental freedoms guaranteed under the Convention, entailed only negative obligations for States Parties to the Convention, ${ }^{10}$ referred to in the literature as Pisillo Mazzeschi (2008) "obligations of the state's absence in the sphere of human rights and freedoms" (p. 187). During the works on the Convention, the state was not perceived as a guarantor of rights and fundamental freedoms, but rather a potential aggressor who, as the wielder of public authority, should abstain from "a certain kind of interference." ${ }^{11}$ This minimalist approach to the role of the state corresponded with the image of an entity entitled to exercise the rights and fundamental freedoms, and thus the beneficiary of the provisions contained in the Convention, implying free and autonomous man who decides

\footnotetext{
Tyrer v. the United Kingdom, No. 5856/72, of 25 April 1978, para. 31.

8 Marckx v. Belgium, No. 6833/74, of 29 October 1975 r., para. 30.

9 See Matthews v. the UK, No. 24833/94, of 18 February 1999 r., para. 39.

10 States Parties to the Convention and the Court itself (previously also the Commission) pay attention to this nature of obligations. See e.g.: X and Yv. the Netherlands, No. 8978/80, judgment of 26 March 1985, para. 23-24 and 27; Evans v. the UK, No. 6339/05, judgment of 10 April 2007, para. 75; Bevacqua and S. v. Bulgaria, No. 71127/01, judgment of 12 June 2008 , para. 64.

${ }^{11}$ Cf. the partially separate dissenting opinion of Judge F. Matscher in Marckx v. Belgium, 1979, point I.
} 
about his own fate and who does not need assistance from the State, opposing instead the latter's interference in his affairs. ${ }^{12}$

The homogeneity of the subject matter of obligations under the Convention for States Parties, and thus their internal structure and functions, was questioned by the judicial bodies of the Convention as early as the late 1960s, first by the Commission and later by the Court. (Sudre, 2003, p. 228, \& Xenos, 2011, p. 3 et seq.). In the course of the interpretation and application of the Convention, these bodies began to derive positive obligations for States Parties from the Convention standards protecting human and political rights and freedoms, with negative obligations remaining in the foreground as primary obligations. In other words, the original obligations towards States Parties of the Convention are, above all, negative obligations, ${ }^{13}$ whereas positive obligations have been added to them and supplement them. ${ }^{1415}$ Consequently, their indirect normative bases are commonly accentuated, ${ }^{15}$ often being described as implied obligations. (Dijk, 1998, pp. 17-33, Klatt, 2011, pp. 691-718, Mowbray, 2004, p. 100 et seq., Mowbray, 2010, pp. 289-317, Xenos, 2011, p. 65). ${ }^{16}$

Positive obligations are linked to all human rights and fundamental freedoms, but they have been exceptionally well developed for three rights in particular. Among these rights, the right to respect for private and family life is of particular importance (Art. 8 of the Convention), for which the first judgments were passed, in which the judicial bodies of the Convention drew attention to positive obligations. (Morawska, 2016, pp. 89-92). The other two rights are the prohibition of illtreatment (Art. 3 of the Convention) and the right to life (Art. 2 of the Convention), respectively.

\section{The types of state obligations linked to the right to life}

For the issues outlined in the title of this paper, the most important are the positive obligations derived from Art. 2 of the Convention. In relation to them, emphasis should first be placed on the first sentence in the first paragraph of the Article, according to which the right of every person to life is protected by law, given that it is referred to as a normative justification for positive obligations. For the first time, the Court interpreted it as such explicitly in the case of $L$.

\footnotetext{
12 The very title of the Convention suggests that individual freedom is its fundamental idea.

13 W. v. the UK, No. 10871/84, decision of EComHR of 10 July 1986; Özgür Gündem v. Turkey, No. 23144/93, judgment of 16 March 2000, para. 42

${ }^{14}$ Marckx v. Belgium of 1979, para. 31. Similar cases: Broniowski v. Poland, No. 31443/96, judgment of ECtHR of 22 June 2004 , para. 143; Palomo Sánchez and Others v. Spain, No. 28955/06 et al., judgment of 12 September 2011.

15 The parties to the proceedings before the ECtHR also pay attention to this, e.g. in: Osman v. the UK, No. 23452/94, judgment of 28 October 1998, para. 128; Iglesias Gil and A. U. I. v. Spain, No. 56673/00, judgment of 29 April 2003, para. 39 (the applicant's position); Saadi v. Italy, No. 37201/06, judgment of 28 February 2008, para. 120 (amicus curiae); A. v. the Netherlands, No. 4900/06, judgment of 20 July 2010, para. 128 (amicus curiae); Rantsev v. Cyprus and Russia, No. 25965/04, judgment of 07 January 2010, para. 268 (amicus curiae-Interrights). See also the separate dissenting opinion of Judge P. van Dijk in the case of Shefield and Horsham v. the UK, No. 22985/93, 23390/94, judgment of 30 July 1998, para. 2.

${ }^{16}$ See also L. Wildhaber, The Place of the European Court of Human Rights in the European Constitutional Landscape, Conference of European Constitutional Courts XIIth Congress, text Retrieved from http://www.confeuconstco.org
} 
C. $B v$. the UK, and later in the case of Osman v. the $U K,{ }^{17}$ thus laying the foundations for a future jurisprudence. ${ }^{18}$ Therefore, in the assessment of the Court, Osman v. the UK, para. 115 (1998),

the first sentence of Article $2 \S 1$ enjoins the State not only to refrain from the intentional and unlawful taking of life, but also to take appropriate steps to safeguard the lives of those within its jurisdiction (see the L.C.B. v. the United Kingdom judgment of 9 June 1998, Reports of Judgments and Decisions 1998-III, p. 1403, \$36). It is common ground that the State's obligation in this respect extends beyond its primary duty to secure the right to life by putting in place effective criminal law provisions to deter the commission of offences against the person backed up by law-enforcement machinery for the prevention, suppression and sanctioning of breaches of such provisions. It is thus accepted by those appearing before the Court that Article 2 of the Convention may also imply in certain welldefined circumstances a positive obligation on the authorities to take preventive operational measures to protect an individual whose life is at risk from the criminal acts of another individual.

The above findings prove that Strasbourg case law identifies two general types of actions that States Parties are obliged to undertake in order to fulfill their positive obligations: actions in the area of national law and actions in the area of their implementation. In the case of the right to life, these two areas are not equivalent, since the obligation to ensure the protection of the right to life, by means of appropriate legal provisions, is recognized as a primary obligation, and therefore primordial and superior. It can be assumed that this results from its direct normative justification. On the other hand, it is clear that the Court has not limited the protection of the right to life strictly to the provisions of law, but additionally pointed to the obligation to provide them with real effectiveness in practice, ${ }^{19}$ and has consistently imposed on States Parties an obligation to design enforcement machinery for the prevention, suppression and sanctioning of breaches (violations) of provisions. ${ }^{20}$ At the same time, the obligation to establish the enforcement machinery of internal law has a complex internal structure. First of all, it is an obligation to establish an appropriate mechanism to enforce these provisions in the area of preventing, suppressing and sanctioning any violation of these provisions. ${ }^{21}$ The recipient of this obligation is the national legislator, who is to create a legal framework for the establishment of the machinery and a separate framework for its operation in practice. The very use of this machinery constitutes a separate obligation. ${ }^{22}$

The most important mechanism for the conducted analysis is the prevention of breaches of legal provisions protecting the right to life. The Court's rulings in the case of Osman v. the UK of 1998, cited above, show that it is essential to take appropriate preventive measures to protect a person whose life is threatened by another person. Anticipating the detailed remarks, it should be emphasized that acts of violation of the right to life made by private persons, cf. Dipla (1994), Dröge (2003), Spielmann (1998) and Sudre (1995) "are not attributable to the state" (p. 63; p. 293;

\footnotetext{
${ }_{17}$ Respectively: application No. 23413/94, judgment of 9 June 1998; application No. 23452/94 of 28 October 1998.

18 Cf. Agarkov v. Russia, No. 29951/09, judgment of 15 May 2018, para. 55.

${ }^{19}$ Dodov v. Bulgaria of 2008, para. 83.

${ }^{20}$ Osman v. the UK of 1998, para. 115.

${ }^{21}$ Osman v. the UK of 1998, para. 115.

${ }^{22}$ Osman v. the UK of 1998, para. 115.
} 
p. 169; p. 374 ), but they may constitute, cf. Crawford (2002) and Pisillo Mazzeschi (1992), "only an external fact that gives rise to another unlawful act, effected by the state itself and stemming from failure to comply with the obligation to prevent such actions or punishment by state authorities" (pp. 874-890; p. 26). ${ }^{23}$ The essence of this "other unlawful act" of the state is, thus, to refrain from taking the required actions. Consequently, as aptly pointed out by Sudre (1995),

it is not the conduct of the individual that may be the subject of charges before the ECtHR, but the behavior of the authorities of State Party that has not taken appropriate measures to prevent such violations, analyzed in terms of negligence (p. 374).

The significance of this positive obligation is undisputed in Strasbourg case law. In defining its subject, the Court states that it means to "take appropriate steps to safeguard the lives of those within its jurisdiction" ${ }^{24}$ Importantly, the set of potential threats to the right to life requiring these steps is not closed, because in the Court's assessment "[. . . this obligation is to be interpreted and applied in the context of any activity, whether public or private, in connection with which the right to life may be threatened". 25

\section{Types of preventive obligations related to the right to life}

In light of Art. 2(2) of the Convention, threat to the right to life associated with the use of force with a fatal effect (lethal force) by state officials should be approached with particular caution. Reading it literally, it can be assumed that in a situation of absolute necessity, it allows the state to deprive life through the use of force to achieve the three objectives set out therein. It should, however, be borne in mind that, in the Court's view, this authorization does not in any way constitute a power for the state to use force with the intention to kill. In the legal order of the Convention, the use of force by the State with a fatal consequence is therefore not prohibited if the effect was not intentional, and the use of force was absolutely necessary to achieve the objectives set out in Art. 2(2) of the Convention. ${ }^{26}$ This means that, pursuant to Art. 2 of the Convention, the state is obliged to refrain from intentional and unlawful taking of life, ${ }^{27}$ the content of which should be determined taking into account the autonomous interpretation of the Convention. As a result of its application, the conventional terms gain a certain semantic independence from the internal legal

\footnotetext{
${ }^{23}$ See also International Law Association (2014).

24 Cf. primarily: L.C.B. v. UK of 1998; Osman v. the UK of 1998, para. 115; Paul and Audrey Edwards v. the UK, No. 46477/99, judgment of 14 March 2002, para. 71; and subsequent cases, inter alia: Keenan v. the UK, No. 27229/95, judgment of 3 April 2001, para. 89; Mojsiejew v. Poland of 2009, No. 11818/02, judgment of 24 March 2009, paras 49-50; Jasinskis v. Latvia, No. 45744/08, judgment of 21 December 2010, para. 58; Perevedentsevy v. Russia, No. 39583/05, judgment of 24 April 2014, para. 90.

25 Öneryildiz v. Turkey, No. 48939/99, judgment of 30 November 2004, para. 71.

${ }^{26}$ McCann and Others v. the UK, No. 18984/91, judgment of 27 September 1995, para. 148.

27 Ibidem. See also cases e.g. Calvelli and Ciglio v. Italy, No. 32967/96, judgment of 17 January 2002, para. 48; Vo v. France, No. 53924/00, judgment of 8 July 2004, para. 88; Tarariveva v. Russia, No. 4353/03, judgment of 14 December 2006, para. 73; Dodov v. Bulgaria, No. 59548/00, judgment of 17 January 2008, para. 79; Jasinskis v. Lotva of 2010, para. 58.
} 
orders of States Parties to the Convention. The Court, thus, ascribes to the terms "intentionality" and "unlawfulness" a particular meaning which does not need to be the same as the meanings these terms carry in the legal systems of States Parties to the Convention.

For the first time, the Court determined the conditions for the use of lethal force by the State in the case of McCann and Others v. the UK of 1995. ${ }^{28}$ It follows from it that Art. 2 of the Convention should be so "interpreted and applied that [the] resulting guarantees [of protection of the right to life] are practical and effective", which is self-evident considering the object and purpose of the Convention as an instrument for the protection of human rights. ${ }^{29}$

In this case, the applicants accused the British authorities of violating Art. 2 of the Convention in connection with the killing of their relatives by British SAS (Special Air Service) soldiers, who, according to intelligence gathered by the British and Spanish authorities, were to be members of the Irish Republican Army (IRA) and were planning a terrorist attack in Gibraltar. ${ }^{30}$ According to the applicants, Art. 2 of the Convention imposes on States Parties to the Convention a positive obligation to protect life, which requires, in particular, that national laws strictly specify and restrictively indicate the circumstances in which a state official may use force with a lethal effect. The applicants also argued that this obligation requires States Parties to provide its officials with proper training regarding the use of lethal force and ensure strict supervision over the course of the action in which lethal force may be used. ${ }^{31}$

Although the Court investigated the case with reference to Art. 2 of the Convention, it was not done in the light of positive obligations, but in the light of the criterion of the absolute necessity to use lethal force. It was determined that, due to the criterion in question, the circumstances in which lethal force may be used must be subject to restrictive interpretation ${ }^{32}$ and an extremely accurate assessment, within which not only actions of state officials who actually used lethal force must be taken into account, but all surrounding circumstances as well. ${ }^{33}$ In doing so, the Court combined the new premise with the criterion of the absolute necessity of using lethal force. A review of the case law shows that it is of particular importance, and in fact, leads to the redefinition of the criterion of absolute necessity. Importantly, so far the Court has neither stated its substance precisely nor enumerated situations which it considers to be "all circumstances surrounding the use of this lethal force". The Court did, however, indicate its basic assumption that, in a democratic society, law enforcement officials should "exercise certain caution in the use of firearms, even during actions undertaken against persons suspected of terrorism" ${ }^{34}$. This was later linked to specific obligations, including the obligation to develop a plan of action for using lethal force, the obligation

\footnotetext{
${ }^{28}$ See footnote No. 25.

${ }^{29}$ McCann and Others v. the UK of 1995, para. 146.

${ }^{30}$ McCann and Others v. the UK of 1995, paras. 192-193.

31 McCann and Others v. the UK of 1995, para. 151.

${ }^{32}$ McCann and Others v. the UK of 1995, para. 147 in fine.

${ }_{33}$ McCann and Others v. the UK of 1995, para. 150.

${ }^{34}$ McCann and Others v. the UK of 1995, para. 212.
} 
to properly supervise its course, ${ }^{35}$ the obligation to sufficiently respect the protection of the right to life in instructions given to officials regarding the use of lethal force, ${ }^{36}$ and in particular, the exclusion of the instruction shoot to kill $^{37}$ and the obligation to properly train or instruct officials so that they can assess whether there really is an absolute necessity to use firearms in a given situation. ${ }^{38}$

The performance of these obligations requires a number of specific actions that have a preventive function (Pisillo Mazzeschi, 2008, p. 398), and as such, are aimed at "minimizing, to the largest possible extent, the use of lethal force" ${ }^{39}$ It should be noted that they do not exhaust possible preventive measures. In conclusion to its findings, the Court ruled that

having regard to the decision not to prevent the suspects from travelling into Gibraltar, to the failure of the authorities to make sufficient allowances for the possibility that their intelligence assessments might, in some respects at least, be erroneous and to the automatic recourse to lethal force when the soldiers opened fire, the Court is not persuaded that the killing of the three terrorists constituted the use of force which was no more than absolutely necessary in defence of persons from unlawful violence within the meaning of Article 2 para. 2 (a) of the Convention. ${ }^{40}$

The direction of change in the planning and supervision of law enforcement operations, as indicated in the case of McCann and Others of 1995, ${ }^{41}$ was maintained in subsequent cases. ${ }^{42}$ Their analysis clearly shows that the Court has been gradually expanding the scope and subject matter of these obligations, as evidenced e.g. by the case of Wasilewska and Kalucka v. Poland of 2010, which implies that law enforcement officials joining the action with the use of lethal force must wear an obvious identification mark, so that there is no doubt as to them being law enforcement officials. In addition, the authorities, "by planning an action involving a large number of law enforcement officials and an unknown number of suspects" were obliged to provide an ambulance on the spot. ${ }^{43}$ In turn, in the case of Andronicou and Constantinou v. Cyprus of 1997, the Court for the first time drew attention to the obligation of planning and control of the rescue operation. ${ }^{44}$ The subject

\footnotetext{
35 McCann and Others v. the UK of 1995, para. 150.

36 McCann and Others v. the UK of 1995, para. 201.

37 The Court has repeatedly expressed criticism about such instructions, cf. in the case of Giuliani and Gaggio v. Italy, No. 23458/02, 24 March 2011, para. 250; previously in the ECtHR's judgment in Nachova and Others v. Bulgaria, No. 43577/98 and 43579/98, judgment of 6 July 2005, para. 97; Putintseva v. Russia, No. 33498/04, judgment of 10 May 2012, para. 47.

${ }^{38}$ McCann and Others v. the UK of 1995, para. 212, in fine, this obligation was repeated in a series of subsequent judgments, e.g. in Wasilewska and Katucka v. Poland of 2010, para. 47, and in Giuliani and Gaggio v. Italy of 2011, para. 250.

39 McCann and Others v. the UK of 1995, para. 194; Wasilewska and Katucka v. Poland, No. 28975/04 and 33406/04, judgment of 23 February 2010, para. 29.

40 McCann and Others $v$. the UK of 1995, para. 213.

41 Analyses in this area are usually separated and titled planning and conduct of the operation.

42 Andronicou and Constantinou v. Cyprus, No. 25052/94, judgment of 9 October 1997; Güleçv. Turkey, No. 21593/93, judgment of 27 July 1998, para. 71; Giuliani and Gaggio v. Italy of 2011, para. 255; Isayeva, Yusupova and Bazayeva v. Russia, No. 57947/00 et. al, judgment of 24 February 2005; Finogenov and Others v. Russia, No. 18299/03 and 27311/, of 20 December 2011. See also cases related to the operation of rescuing hostages held at a school in Beslan, North Ossetia, Russia: Tagayeva and Others v. Russia, No. 26562/07 et. al., judgment of 13 April 2017, in which the Court made an anti-terrorist assessment of the operations of the Russian services (from 1 to 3 September 2004), undertaken in connection with the terrorist occupation of a school in Beslan, North Ossetia, Russia.

43 Application No. 28975/04 33406/04, judgment of Chamber of 23 February 2010, para. 55.

${ }^{44}$ Andronicou and Constantinou v. Cyprus of 1997, especially paras. 181-186.
} 
of this obligation may be related to the one formulated in the case of Ergi v. Turkey of 1998, that is that of avoiding and, in any event, minimizing, incidental loss of civilian life. ${ }^{45}$ To show the structure of this obligation, it is necessary to distinguish at least three types of action (operations). A distinction should be made between a rescue operation consisting in the evacuation of individuals during a typical police action and a rescue operation that requires planning and carrying out a mass evacuation of individuals whose lives are at risk in a given situation, and then, the act of evacuating civilians from areas affected by armed conflict. ${ }^{46}$ Thus, the scope of this obligation to act was not limited to typical police operations. The Court drew attention to the obligation to carry out these last types of rescue operations in many cases against Russia, in connection with operations conducted by the Russian federal security forces and the Russian military in Chechnya. One such case was Isayeva v. Russia of 2005, in which the Court investigated the circumstances of planning and conducting the evacuation of civilians from the village of Katyr-Yurt, in which Chechen rebels were hiding and who were fired at by Russian troops with indiscriminate weapons. Once again, the Court emphasized in its assessment that

in the light of the importance of the protection afforded by Article 2, the Court must subject deprivations of life to the most careful scrutiny, taking into consideration not only the actions of State agents but also all the surrounding circumstances. 175. In particular, it is necessary to examine whether the operation was planned and controlled by the authorities so as to minimise, to the greatest extent possible, recourse to lethal force. The authorities must take appropriate care to ensure that any risk to life is minimised. The Court must also examine whether the authorities were not negligent in their choice of action. ${ }^{47}$

Ultimately, the Court found that the evacuation of the civilian population from KatyrYurt and the entire military operation had not been "planned and carried out with due care for the civilian population" and ruled a violation of Art. 2 of the Convention. ${ }^{48}$

\section{The criteria of the Court's assessments}

As was emphasized at the outset, both the case of Osman and the case of McCann and Others are leading cases and both determined the Court's jurisprudence on the need to prevent the materialization of the threat to the right to life. While in the first case it was about the threat from private persons or external factors towards the state, in the latter case the issue concerned state officials. Both cases have the obligation of prevention at their core, which prevention is not just

\footnotetext{
${ }^{5}$ Ergi v. Turkey, No. 23818/94, judgment of 28 July 1998, para. 80 et seq.; particular significance of this judgment is highlighted by Dröge (2003, p. 46), Mowbray (2004, p. 13) and Pisillo Mazzeschi (2008, p. 399).

${ }^{46}$ It should be emphasized that in the case of the latter action, the Court's findings clearly enter into the sphere of international humanitarian law and give rise to important critical remarks. See Jachec-Neale (2010, p. 119-142).

47 Isayeva v. Russia, No. 57950/00, judgment of 24 February 2005, paras. 170-171.

${ }^{48}$ Isayeva v. Russia, No. 57950/00, judgment of 24 February 2005, para. 199. Similar conclusions were drawn for Abuyeva and Others v. Russia, No. 27065/05, judgment of 2 December 2010, para. 203.
} 
criminal prevention sensu stricto, but it refers instead to a whole range of different organizational, technical and tactical measures, including tactics and techniques of prevention and intervention of broadly understood police and preventive services, special forces and the military. In all this, the multidimensional protective function of these measures is important. ${ }^{49}$ Their protective function seems to be superior to other functions, expressing the purpose and object of the Convention most fully. The preventive function is the result of their protective function, and in this sense, it can be considered as a complementary function. In summary, in the cases of McCann in Osman, the Court formulated the essential elements of the obligation of protection: in the vertical dimension in the case of McCann, and in the horizontal dimension in the case of Osman. ${ }^{50}$

Both cases show that the Court optimizes the requirements as to how to carry out the duties formulated therein based on the specific circumstances. ${ }^{51}$ In this case, the violation of the Convention may result from the fact that State Party has failed to take all possible measures which should or may have been taken in the particular circumstances of the case. (Pisillo Mazzeschi, 1992, p. 30). ${ }^{52}$ Therefore, when assessing the case of Finogenov and Others v. Russia and the operation of Russian services and special forces, whose aim was to release about 900 hostages from the Moscow Dubrovka theater building, ${ }^{33}$ the Court determined that it is about taking such measures that are "feasible" in the circumstances. ${ }^{54}$ As a result of the above optimization, the degree of performance of the protection obligations analyzed may vary (Dröge, 2003, p. 310), although it must be the highest possible. ${ }^{55}$

In the assessment of taking the measures in question, their operational aspect is extremely important, which results in obvious "difficulties in maintaining order in contemporary societies, unpredictability of human behavior and decisions during action (operational decisions) in relation to its primary objectives and feasible measures". ${ }^{56}$ In assessing the undertaking of operational preventive measures, a certain randomness is allowed, and thus the possibility of occurrence of accidental, completely unpredictable circumstances. ${ }^{57}$ This, in turn, makes them made bear some risk of non-performance. (Pisillo Mazzeschi, 2008, p. 285). Therefore, the Court allows for an

\footnotetext{
49 The measures required by the Court are aptly described by A. Mowbray as protective police measures. Mowbray (2004, p. 15).

${ }^{50}$ More about the specific nature of the obligation to protect in the legal order of the ECHR and the distinctiveness of their typology in relation to the concept of tripartie typology, i.e. obligation to respect, obligation to protect and obligation to fulfill, see Morawska (2016, pp. 179-187).

${ }^{51}$ Osman v. the UK of 1998, para. 116.

52 See J. Crawford's remarks regarding to the findings in Colozza v. Italy of 1985, para. 61; in this context, cf. findings of the International Court of Justice in the judgment in the case Application of the Convention on the Prevention and Punishment of the Crime of Genocide (Bosnia and Herzegovina v. Serbia and Montenegro) of 26 February2007, I.C.J. Reports 2007 , p. 43.

${ }^{53}$ In this case, the applicants were either hostages or relatives of hostages who died in the course of the action undertaken by the Russian services or died later due to wounds.

${ }^{54}$ Finogenov and Others v. Russia of 2011, para. 209.

${ }_{55}$ For this reason, e.g. in Dodov v. Bulgaria of 2008, it stated that "in a situation where there is no doubt that the police could do more in a given case, the decisive question is whether its response was appropriate to the circumstances, including specific facts and real conditions of everyday police work". See. Dodov v. Bulgaria of 2008, para. 101.

${ }^{56}$ Makaratzis v. Greece, No. 50385/99, judgment of 20 December 2004, para. 69.

57 This unpredictability in the work of law enforcement officials also exists today, despite the development of new technologies and police techniques, because these services face new challenges that were not even foreseeable in the course of work on the Convention; see the findings in Austin and Others v. the UK, No. 39692/09 et al., judgment of 15 March 2012, para. 56.
} 
erroneous assessment of the absolute necessity to use lethal force at a given moment, as long as it was based on a "sincere belief which, for important reasons [at the time of making the decision to use this force], could be considered right, but which then turned out to be wrong". 58

As far as operational preventive measures are concerned, which State Party to the Convention is obliged to undertake in order to implement the horizontal obligation to protect, the Court refers to them as being appropriate or reasonable and appropriate. Therefore, certain flexibility is assumed, which is to help State Parties adjust their specific form to the conditions of the case.

Considering that it is a matter of choosing appropriate and reasonable measures, the rational assessment of factual and legal possibilities indispensable in this case manifests itself in the fact that many external factors, often independent of the state's operation, influence the choice of these measures in a particular case. Accordingly, State Party is required to exercise due diligence in seeking to ensure effective protection to the right to life (Art. 2 of the Convention) to the largest extent a given situation allows it.

If one were to refer these findings to the general criterion of appropriateness and reasonableness of the operational measures required, it becomes obvious that they cannot be means that result in unfeasible or disproportionate burdens for the authorities. ${ }^{59}$ In this way, an important criterion for the fulfillment of obligations resulting from civil and political rights, among them notably the right to life, becomes the criterion of due diligence, which has traditionally been associated with progressive obligations related to economic, social and cultural rights. (International Law Association, 2014, p. 14 et seq).

This conclusion, however, requires a significant supplementation. First, the obligation of due diligence does not refer to negative obligations, the object of which can be reduced to refraining from unlawful and arbitrary interference with human rights and fundamental freedoms, including the right to life. (Pisillo Mazzeschi, 1992, p. 22, 25 e 46). This, in turn, means that the Court, by imposing on States Parties of the Convention the obligation of "planning and monitoring [operations involving the use lethal force] in such a way as to minimize, to the largest possible extent, its use and threat to life" ${ }^{60}$, does not alter the nature and subject of prohibition of intentional or unlawful deprivation of life, but rather "encloses it" with the duties of due diligence. Thanks to it, the Court strengthens the general obligation of States Parties to the Convention in the area of protection of the right to life (first sentence in Art. 2(1) of the Convention).

However, with respect to these "added" duties, the State Party has much less freedom in choosing the means of performing those duties, as the Court clearly established what kind of measures the State is obliged to undertake so as to "minimise, to the greatest possible extent, the use

\footnotetext{
${ }_{58}$ McCann and Others v. the UK of 1995, para. 200; Armani Da Silva v. the UK, No. 5878/08, judge of ECtHR of 30 March 2016, paras. 244-248, and especially Toubache v. France, No. 19510/15, judgment of 7 June 2018, para. 37; Pisillo Mazzeschi (1992, p. 48) and Schutter (2012, p. 414).

59 Ibidem; similarly, inter alia, in Özgür Gündem v. Turkey of 2000, para. 43. Cf. also F. Sudre's remarks: Sudre (2003, p. 237).

${ }^{60}$ Isayeva, Yusupova and Bazayeva v. Russia of 2005, para. 171; similarly in Tagaveva and Others v. Russia of 2017, para. 198.
} 
of lethal force" ${ }^{61}$ Although the catalog of these means is open, they have been explicitly indicated by the Court. As a result, the state has a relatively small margin in means-selecting. For example, State Party joining an action involving the use of lethal force is obliged to develop a plan of such action. Its lack may be in breach of Art. 2 of the Convention. A similar reasoning applies to the provision of an ambulance at the scene of the action or proper training of officials. Elements of optimization or reasonableness of orders emerge only at the stage of operation, i.e. taking direct action with a view to performing a specific task. This is confirmed, for example, by the findings of the Court in the case of Giuliani and Gaggio v. Italy of 2011, according to which, in a situation where officials do not recourse to lethal force against a precise and identifiable target, as was in the case of McCann and Others, but for "keeping order in the face of riots that could have spread [. . .] throughout the city, one cannot expect all officials participating in this action are perfectly trained in dealing with the task entrusted to them". ${ }^{62}$

Second, as indicated above, not all types of specific obligations under the obligation to protect the right to life (Art. 2 of the Convention) have in their structure "the element of diligence1". ${ }^{63}$ In other words, the content of the obligation to protect the right to life, both horizontally and vertically, consists of many different duties, only a few of which are duties of due diligence. For example, the obligation to protect the right to life in a horizontal dimension requires, first of all, establishing appropriate, effective criminal law provisions to prevent crimes against a person (legislative obligation), then establishing appropriate mechanisms for enforcing these provisions at the level of preventing, suppressing and prosecuting the offenders of these violations. ${ }^{64}$ In the structure of the aforementioned obligations, there is no requirement of due diligence, as they are obligations outcome-related and immediate, and therefore require prompt execution. ${ }^{65}$ The obligation of due diligence emerges only at the stage of using these mechanisms in practice, including via operational preventive or precautionary means. (Dröge, 2003, p. 290 et seq.). ${ }^{66}$

\section{Conclusion}

Due diligence is a constitutive element of the good faith principle. A State is acting in good faith if, despite due diligence in the actions taken, it could not fulfill its obligations. On the contrary, if the state does not exercise due diligence, it is acting in bad faith.

\footnotetext{
${ }^{61}$ McCann and Others v. the UK of 1995, para. 194; Wasilewska and Katucka v. Poland, No. 28975/04 and 33406/04, judgment of 23 February 2010, para. 29.

62 Giuliani and Gaggio v. Italy of 2011, para. 255.

${ }^{63}$ See accordingly International Law Association (2014, p. 2) and Pisillo Mazzeschi (2008); a similar hypothesis can be put forward regarding the case law of the Inter-American Court of Human Rights. See Velásquez-Rodríguez v. Honduras, judgment of 29 July 1988, para. 166, 172, 177.

${ }^{64}$ Osman v. the UK of 1998, para. 115.

65 See more broadly Morawska (2016, pp. 166-178).

${ }^{66}$ See. Cf. also International Law Association (2014, p. 2); to confirm these findings the case of Kelly and Others v. the UK of 2001, para. 96, was referenced.
} 
In line with popular opinion, it was $\mathrm{H}$. Grocjusz who laid the foundations for the concept of due diligence in international law (Dröge, 2003, p. 292), while the field of international law from which this concept originates is the protection of foreign citizens and representatives of foreign states. (Dröge, 2003, p. 291; Pisillo Mazzeschi, 1992, pp. 22-36). At present, reference to this concept can be found also in other branches of international law, including the protection of human rights. (Barnidge, 2005, pp. 103-125; Koivurova, 2013, nb 33). It has been gradually gaining the status of one of the basic principles of international law (Condorelli, 1989, p. 233-246; Barnidge, 2006, p. 64). As we know, it played a key role in the first phase of the works of the International Law Commission (ILC) on the codification of the principles of state responsibility for unlawful acts. (Koivurova, 2013, nb 4, 9, 27). The wide application of the concept of due diligence is largely due to its flexibility, which allows it to be adapted to the specifics of a given branch of international law and a specific case, because its content depends to a large extent on the circumstances of the case. ${ }^{67}$

The analysis of international practice in the field of human rights protection shows that, originally, the concept of due diligence was invoked only in the context of preventive and investigative actions of the authorities, required in the event of violations of human rights by third parties (Koivurova, 2013, nb. 31; Pisillo Mazzeschi, 2008, p. 493;). The preventive, and at the same time protective, context of the concept of due diligence, having its historical sources, can also be observed in the most recent international case law. ${ }^{68}$ This relationship seems to arise from the specificity of the areas in which the state takes action of this type, in which case arriving at the outcome would be very difficult, and certainly could not be fully guaranteed. ${ }^{69}$ In this case, the expectation of due diligence from the State was, and is, a certain rational necessity. Nevertheless, the requirement of due diligence increasingly often necessitates going beyond the scope of preventive measures to suppress violations of human rights by private individuals, ${ }^{70}$ as a result of which the concept of due diligence also applies to actions to prevent human rights violations undertaken in the vertical dimensions. Consequently, States are obliged to protect persons under their jurisdiction over the actions of their own bodies (officials), which are not unlawful prima facie. ${ }^{71}$

The above process of extending the scope of due diligence can be observed in Strasbourg case law. It seems that it was initiated in the case of McCann and has been consistently upheld

\footnotetext{
${ }^{67}$ In the context of introducing the concept of due diligence cf. Alabama Claims Arbitration (United States v. Great Britain) (1872) 29 RIAA 125, Alabama Claims of the United States of America against Great Britain, [in:] Reports of International Arbitral Awards, vol. 29, New York 2011, p. 129, retrieved from http://legal.un.org.

68 See Application of the Convention on the Prevention and Punishment of the Crime of Genocide (Bosnia and Herzegovina v. Serbia and Montenegro), judgment of ICJ of 26 February 2007, I.C.J. Reports, p. 43; Forlati (2011, pp. 189-205), Reisman (2011, pp. 370-371) and Wolfrum (2010, pp. 363-383), the preventive nature of the obligations is also highlighted by Dröge (2003, p. 290).

${ }^{69}$ Dupuy (1977, pp. 369-379); similarly Hanqin (2003, p. 163).

70 This aspect is highlighted, inter alia, by Dröge (2003, p. 293); See also Shelton (1989, pp. 1-34).

${ }^{71}$ In the opinion of Dupuy, commitment to prevention is only one of the subcategories of the due diligence rule. See. Dupuy (1999, p. 380).
} 
by the Court. ${ }^{72}$ As a result of this process, the findings of the present case now have the status of general principles. ${ }^{73}$ It should therefore go without saying that States Parties to the Convention nowadays have a duty to act diligently in certain situations so as to "minimize, to the greatest possible extent, the use of lethal force or accidental deaths" ${ }^{74}$ In other words, States Parties were obliged to "make every effort" to fulfill this obligation, while assuming that there could be reasons for an objective inability to do so, as a number of highly uncertain, random factors are at play ${ }^{75}$. However, it should be borne in mind that in assessing the State's due diligence in a given case, the Court has consistently taken into account "the ever-higher standard required in the field of human rights and fundamental freedoms [. . .] and demonstrates increasingly more determination in assessing violations of the basic values of a democratic society" ${ }^{76}$ There is, thus, no single, constant, required level of due diligence. Not only that, it is also being constantly increased. The analysis of Strasbourg case law shows that this applies in full to the actions taken by States Parties in the implementation of the obligation to protect the right to life.

\section{References}

Barnidge, R. P. (2005). States' Due Diligence Obligations with Regard to International Non-State Terrorist Organisations Post-11 September 2001: The Heavy Burden that States must Bear. Irish Studies in International Affairs, 16(1): 103-125.

Barnidge, R. P. (2006). The Due Diligence Principle Under National Law. International Community Law Review, 8(1), 81-121.

Bates, E. (2010). The Evolution of the European Convention on Human Rights: From its Inception to the Creation of a Permanent Court of Human Rights. UK: Oxford University Press.

Condorelli, L. (1989). The Imputability to States of Acts of International Terrorism in. Israel Yearbook on Human Rights, (19), 233-246.

Crawford, J. (2002). The ILC's Articles on Responsibility of States for Internationally Wrongful Acts: A Retrospect. American Journal of International Law, 96(4): 874-890.

\footnotetext{
72 See relatively recent cases of: Ayvazyan v. Armenia, No. 56717/08, judgment of 1 June 2017; Dalakov v. Russia, No. 35152/09, judgment of 16 February 2016.

73 Putintseva v. Russia, No. 33498/04, judgment of 10.05 .2012 r., para. 45.

74 Wasilewska and Kałucka v. Poland of 2010, para. 46; Putintseva v. Russia, No. 33498/04, of 10 May 2012, para. 45; see also International Law Association (2014, pp. 14-22).

75 Pisillo Mazzeschi (1992, p. 48 mutatis mutandis).

${ }^{76}$ Cf.: A. v. Croatia, No. 55164/08, judgment of 14 October 2010, para. 67; Henaf v. France, No. 65436/01, judgment of 27 November 2003, para. 55; these arrangements relate not only to Article 8 of the Convention, but also to other human rights and fundamental freedoms. Cf. Mangouras v. Spain, No. 12050/04, judgment of ECHR of 28 September 2010, para. 87; Demir and Baykara v. Turkey, No. 34503/97, of 12 November 2008, para. 146; Siliadin v. France, No. 73316/01, of 26 July 2005, para. 121; previously e.g. in Selmouni v. France, No. 25803/94, of 28 July 1999, para. 101.
} 
Dijk, P. (1998). Positive Obligations Implied in the European Convention on Human Rights: Are the States Still the "Master" of the Convention. In M. H. F. Castermans-Holleman, \& J. Smith (Eds.), The Role of the Nation-State in the 21st Century: Human Rights, International Organisations, and Foreign Policy: Essays in Honour of Peter Baehr. Leiden, Netherlands: Brill-Nijhoff.

Dipla, H. (1994). La responsabilité de l'Etat pour violation des droits de l'homme. Problèmes d'imputation. Paris, France : Editions A. Pedone.

Dröge, C. (2003). Positive Verpflichtungen der Staaten in der Europäischen Menschenrechtskonvention. Berlin, Germany: Springer.

Dupuy, P.-M. (1977). Due Diligence in the International Law of Liability. In Organisation for Economic Co-operation and Development (Ed.), Legal Aspects of Transfrontier Pollution. Paris, France: OECD.

Dupuy, P.-M. (1999). Reviewing the Difficulties of Codification: on Ago's Classification of Obligations of Means and Obligations of Result in Relation to State Responsibility. European Journal of International Law, 10(2), 371-385.

Forlati, S. (2011). The Legal Obligation to Prevent Genocide: Bosnia v. Serbia and Beyond Polish Yearbook of International Law, (31), 189-205.

Gordon, D. A. J., \& Leach P. (2012). The UK and the European Court of Human Rights. London, UK: London Metropolitan University.

Hanqin, X. (2003). Transboundary Damage in International Law. UK: Cambridge University Press.

International Law Association. (2014, March 7). First Report ILA Study Group on Due Diligence in International Law. Retrieved from http://www.ila-hq.or

Jachec-Neale, A. (2010). The Right to Take Life: Killing and Death in Armed Conflict. In J. Yorke (Ed.), The Right to Life and the Value of Life: Orientations in Law, Politics, and Ethics. Farnham, Surrey, UK: Ashgate Publishing.

Keller, H., \& Sweet A. S. (2008). A Europe of rights. The impact of the ECHR on National Legal System. UK: Oxford University Press.

Klatt, M. (2011). Positive Obligations under the European Convention on Human Rights. Zeitschrift für ausländisches öffentliches Recht und Völkerrecht, 71(4): 691-718. 
Koivurova, T. (2013). Due Diligence, Max Planck Encyclopedia of Public International Law (MPEPIL). UK: Oxford University Press.

Moravcsik, A. (2000). The Origins of Human Rights Regimes: Democratic Delegation. Post-war Europe, International Organization, 54(2), 217-252.

Morawska, E. H. (2016). Zobowiązania pozytywne państw-stron Konwencji o ochronie praw człowieka $i$ podstawowych wolności [Positive obligations of States Parties to the Convention for the Protection of Human Rights and Fundamental Freedoms]. Warsaw, Poland: Cardinal Stefan Wyszyński University.

Mowbray, A. (2010) A Study of the Principle of Fair Balance in the Jurisprudence of the European Court of Human Rights. Human Rights Law Review, 10(2), 289-317.

Mowbray, A. (2004). The Development of Positive Obligations under the European Convention on Human Rights by the European Court of Human Rights. UK: Oxford University Press.

Osman v. the UK, para. 115 (1998).

P. H. Teitgen's notable speech. (1975). Collected Edition of the "Travaux Préparatoires" of the ECHR, 1, 292-294.

Pisillo Mazzeschi, R. (2008). Responsabilté de l'État pour violation des obligations positives relatives aux droits de l'homme. Collected Courses of the Hague Academy of International Law-Recueil des Cours, 333.

Pisillo Mazzeschi, R. (1992). The Due Diligence Rule and the Nature of the International Responsibility of States. German Yearbook of International Law, (35), 9-51.

Reiss, J. E. (2009). Protocol no 14 ECHR and Russian Non-ratification: the Current State of Affairs. Harvard Human Rights Journal, (22), 293-317.

Robertson, A. H. (1963). Human Rights in Europe. UK: Manchester University Press.

Schutter, O. (2012). International Human Rights Law: Cases, Materials, Commentary. UK: Cambridge University Press.

Shelton, D. (1989). Private Violence, Public Wrongs and the Responsibility of States. Fordham International Law Journal, 13(1), 1-34. 
Spielmann, D. (1998). Obligations positives et effet horizontal des dispositions de la Convention. In F. Sudre (Ed.), L'interprétation de la Convention européenne des droits de l'homme. Bruxelles, Belgium: Bruylant.

Sudre, F. (2003). Droit européen et international des droits de l'homme. Paris, France: Presses Universitaires De France.

Sudre, F. (1995). Les «obligations positives» dans la jurisprudence europeenne des droits de l'Homme. Revue Trimestrielle des Droits de l'Homme, (23), 363-385.

Wolfrum, R. (2010). Obligation of Result versus Obligation of Conduct: Some Thought about the Implementation of International Obligations. In M. H. Arsanjani, \& W. M. Reisman (Eds.), Looking in the Future: Essays on International Law in Honor of W. Michael Reisman. Netherlands: Brill-Nijhoff.

Xenos, D. (2011). The Positive Obligations of the State under the European Convention of Human Rights. Abingdon, UK: Routledge. 
